\title{
VALUES OF SERUM C-REACTIVE PROTEIN AND SALIVARY IMMUNOGLOBULIN IGA IN DIABETIC PATIENTS: RELATION TO THE SEVERITY OF PERIODONTAL DISEASE
}

\author{
NAZDAR MOHAMMED OMER, BDS, MSC (ORAL PHYSIOLOGY)* \\ QASIM H. ABDULLAH, MBCHB, MSC, PHD (CLINICAL PHYSIOLOGY)** \\ RAED S. AL-NAEMI, BVM, MSC, PHD (MEDICAL PHYSIOLOGY)***
}

\section{Submitted 12 April 2020; accepted 23 July 2020}

\begin{abstract}
Background: Altered immune response and improper neutrophils chemotaxis, phagocytosis, and adhesion might be the principal causative factor for increased susceptibility to periodontal pathogens and oral complications in diabetic patients. This study aimed to determine the relationship between C-reactive protein and salivary IgA with periodontal disease and the severity of dental caries with the glycemic control state of patients with diabetes mellitus.

Patients and Methods: This study was carried out on 91 subjects, 61 patients with diabetes mellitus, and 30 apparently healthy subjects (as a control group). The patient groups were regularly attended Duhok Diabetes Center, Duhok City, Kurdistan Region (Iraq) for diabetes management. The healthy controls were recruited from the staff and sub staff of Azadi Teaching Hospital. Fasting plasma glucose, HbAlc, and serum high sensitivity C-reactive protein (Hs-CRP) were measured. The whole saliva collection was performed by an unstimulated method for five minutes in a graduated test tube to recognize the salivary secretion rate and then stored at $-20{ }^{\circ} \mathrm{C}$ for IgA estimation. Periodontal Index was used to determine the periodontal disease status. Each tooth was scored according to the condition of the surrounding tissues.
\end{abstract}

Results: Significantly higher Hs-CRP ( 9.2 vs $3.3 \mu \mathrm{g} / \mathrm{ml})$, fasting plasma glucose (215.4 vs 98.9 $\mathrm{mg} / \mathrm{dl})$ and HbA1c $(8.5$ vs $4.9 \%),(P<0.001$ for all parameters, together with lower hemoglobin (13.6 vs $14.5 \mathrm{gm} / \mathrm{dl}, \mathrm{P}=0.03$ ) levels were found in diabetic patients compared to control group, A significantly higher mean salivary IgA level in diabetic patients compared to controls ( 312.4 vs $177.3 \mathrm{mg} / \mathrm{dl}, P<0.001)$, associated with a significant high periodontal index (1.68 vs $0.81, P=0.003)$.

Conclusion: Elevated serum Hs-CRP and salivary IgA in patients with diabetes mellitus as inflammatory response sequences raise inflammation potential in the periodontium. Further, the results confirm that periodontal index was associated with poor glycemic control.

Duhok Med J 2020; 14 (2): 40-50

Keywords: Hs-CRP, IgA, Periodontal disease, Periodontal index

\begin{tabular}{|c|c|}
\hline $\begin{array}{l}\text { D pidemiological data support } \\
\text { microvascular changes in diabetes } \\
\text { mellitus }(\mathrm{DM})^{1} \text {. The microvascular changes } \\
\text { lead to reduced tissue blood flow, decreased } \\
\text { oxygen diffusion, and a better environment } \\
\text { for the growth of anaerobic bacteria and } \\
\text { susceptibility to infection }{ }^{2} \text {. The possible } \\
\text { association between oral and systemic }\end{array}$ & $\begin{array}{l}\text { health has been highlighted; evidence } \\
\text { suggested a bi-directional relationship } \\
\text { between systemic and periodontal disease. } \\
\text { Oral manifestations in DM include high } \\
\text { dental caries, xerostomia, glossitis, oral } \\
\text { candidiasis, burning mouth, and gingival } \\
\text { and periodontal disease }{ }^{3,4} \text {. The altered } \\
\text { immune response and improper neutrophils }\end{array}$ \\
\hline
\end{tabular}

\footnotetext{
* Assis. Lecturer, Dep. of Medical Physiology and Pharmacology, College of Medicine, University of Duhok, Kurdistan Region, Iraq.

** Professor, Dep. of Medical Physiology and Pharmacology, University of Duhok, Kurdistan Region, Iraq. *** Professor, Dep. of Medical Physiology and Pharmacology, University of Duhok, Kurdistan Region, Iraq. 
chemotaxis, phagocytosis, and adhesion2 might be the principal causative factor for increased susceptibility to periodontal pathogens and oral complications 5 . Reduction in the quantity of salivary secretion or changes in its properties is responsible for oral and dental problems ${ }^{6}$. Salivary immunoglobulin A (s-IgA) antibodies could help oral immunity by preventing microbial adherence, neutralizing enzymes, toxins, and viruses. Studies have demonstrated a lower incidence of dental caries as a result of high s-IgA concentration, and low levels have been presented as a risk factor for upper respiratory infection, periodontal disease, and dental caries ${ }^{7}$. On the other hand, numerous studies in the last decade have shown that CRP is an independent predictor of risk for periodontal disease. This work was designed to determine the relationship between C-reactive protein, salivary IgA, and glycemic control with the severity of periodontal disease in diabetic patients.

\section{PATIENTS AND METHODS:}

This cross-sectional study was conducted at the Department of Physiology, College of Medicine, University of Duhok and Azadi Teaching Hospital in Duhok city, sixty-one patients with diabetes mellitus (45 with type 2 diabetes and 16 with type 1 diabetes) attended Duhok Diabetes Center, were selected randomly, (35) males and (26) females with ages ranged between 20-55 years. The healthy controls were recruited from the staff and sub-staff of the Azadi Teaching Hospital. Their age and sexmatched with the diabetic group; this group consisted of (19) males and (11) females and with ages ranged between 24- 51 years. All participants were informed about the study, and written consents were obtained before the study commenced. The study was approved by the local ethics committee of the Directorate of Health-Duhok. Exclusion criteria are patients with recent acute illness or upper respiratory tract infection in the past one week, history of chronic liver or renal disease, and those taking antibiotics or who underwent periodontal therapy one month before the study $^{7}$, pregnant females, and alcoholics.

Data collection: all subjects completed a pre-tested questionnaire, which included anthropometric data and a diabetes record. Body mass index and duration of the diabetes were recorded. History was taken to select healthy subjects (controls) and to exclude those with a known personal or family history of diabetes mellitus or the presence of any of the mentioned abnormalities (exclusion criteria).

$\mathrm{HbA1c} \%$ was estimated using a commercial kit (StanbioGlycohemo-globin Pre-fil procedure no. P350), a qualitative colorimetric determination of glycolhemoglobin in whole blood. Estimation of Serum Hs-CRP level using AccuBind HsCRP ELISA kit, product code: 3125-300 (Netherlands), was used for quantitative estimation of serum Hs-CRP. The reaction between various CRP antibodies and native CRP forms a sandwich complex that binds with streptavidin-coated to the well. After equilibrium is attained, the antibody-bound fraction is separated by decantation or aspiration. The enzyme activity presents on the surface of the well quantitated by reaction with a suitable substrate to produce color that is directly proportional to the native antigen concentration. A dose response curve was used to ascertain the concentrations of CRP in the samples. The 
quantitative determination of salivary $\operatorname{IgA}$ was measured by turbidimetry method using Vital Diagnostics IgA Turbidimetry kit (ACCC 16-010). The reference range provided by the manufacturer $(70-400$ $\mathrm{mg} / \mathrm{dl})$.

Assessment of the HbA1c, CRP, and IgA The Assessment HbA1c (\%) at the universal diagnostic decision of the cut-off value of $(48 \mathrm{mmol} / \mathrm{mol} ; 6.5 \%)$ was considered:

Normal $=(<5.7 \%)$ Prediabetes $=(5.7 \%-$ $6.4 \%) \quad$ Diabetes $=\quad(\geq \quad 6.5 \%)$ And for glycemic control HbA1c (\%) in diabetic patients was considered: Good control $(<6.5 \%)$ Fair control $(>6.5 \%$ $-<7.5 \%)$ Poor control $(>7.5 \%)^{8}$.

The assessment of CRP and IgA was done by using the calculated cut-off value formula:

Cut off value $=$ mean $+3 \mathrm{SD}^{9}$. The clinical cut-off value for Hs.CRP $=5.1(\mu \mathrm{g} / \mathrm{ml})$ and for salivary $\operatorname{IgA}=211.3 \mathrm{mg} / \mathrm{dl}$. The result of higher than $5.1(\mu \mathrm{g} / \mathrm{ml})$ for Hs.CRP and $211.3 \mathrm{mg} / \mathrm{dl}$ for IgA provided prognostic information as a risk values for periodontal diseases.

Salivary, Oral and Dental Assessment

- Assessment of Salivary Secretion Rate (SSR) was determined by measuring the amount of unstimulated saliva produced (collected) in a given period of time ${ }^{10}$.

- The Salivary Flow Index (SFI) for unstimulated saliva was used, and subjects were classified into 3 categories $^{11}$ : Normal: 0.25-0.35 ml/min., Low: 0.1-0.24 ml/min., Very low (Hyposalivation): less than 0.1 $\mathrm{ml} / \mathrm{min}$.

- Assessment of Periodontal Index (PI) or Score: Periodontal Index determines the periodontal disease status. Each tooth is scored according to the condition of the surrounding tissues.

On examination, each tooth is assigned a score (from zero to eight) using the following criteria ${ }^{12}$.

0 : Negative. Neither overt inflammation nor loss of function caused by the destruction of supporting tissue is noted.

1: Mild Gingivitis: overt inflammation in the free gingiva is present, does not circumscribe the tooth.

2: Gingivitis: Inflammation surrounds the tooth; there is no apparent break in the epithelial attachment.

6: Gingivitis with pocket formation. The epithelial attachment of the gum to the tooth is broken. There is no interference with normal function. The tooth is not loose or drifting.

8: Advanced destruction with loss of function. The tooth may be loose or drifting. It may sound dull on percussion and maybe depressible in the socket. The scores for each tooth are added, and the total divided by the number of teeth examined. Scores can be interpreted as follows:

0.0-0.2: Clinically normal supportive tissues.

0.3-0.9: Simple gingivitis.

1.0-1.9: Beginning destructive periodontal disease.

2.0-4.9: Established destructive periodontal disease.

5.0-8.0: Terminal periodontal disease.

- Assessment of Decayed, Missed, and Filled Teeth (DMFT) Index or Score

To arrive at a DMFT score for an individual subject's mouth, three values must be determined the number of teeth with carious lesions, the number of extracted teeth, and the number of teeth with fillings 
or crowns ${ }^{13,14}$. Participants were divided into three groups according to their DMFT score:

Group A: DMFT score 0-6

Group B: DMFT score 7-12

Group C: DMFT score13 and more.

\section{STATISTICAL ANALYSES}

All data were analyzed using the Statistical Package for Social Science (SPSS) version 22.0; independent $t$-test and one-way ANOVA test were used to examine statistical differences between groups.

\section{RESULTS}

Table 1, shows the baseline characteristics of the studied individuals. No significant differences were found with respect to age and BMI between the diabetic and healthy control groups. Significantly higher fasting plasma glucose, Hs-CRP, and HbA1c levels were observed in diabetic patients compared to healthy controls $(\mathrm{P}=0.010$ for all parameters). Regarding salivary IgA and periodontal index, a significantly higher mean $\operatorname{Ig} \mathrm{A}$ and the periodontal index was found in the diabetic group compared to the healthy control group $(P<0.001, P=0.003$, respectively). No significant differences were found with respect to salivary secretion rate and DMFT score between the two groups A higher periodontal index (1.86 vs. 1.19$)$ and DMFT score (9.0 vs. 6.6) was observed among patients with type 2 DM compared to patients with type I DM, but the difference was not significant. No significant differences were found with respect to Hs-CRP, salivary secretion rate, and salivary $\operatorname{IgA}$ levels between both types of diabetes.

No significant differences were found with respect to salivary secretion rate and DMFT score between the two groups. A higher periodontal index (1.86 vs 1.19) and DMFT score (9.0 vs 6.6) was observed among patients with type 2 DM compared to patients with type I DM, but the difference was not significant. No significant differences were found with respect to HsCRP, salivary secretion rate, and salivary IgA levels between both types of diabetes.

\begin{tabular}{llll}
\hline \multicolumn{4}{c}{ Table 1: Baseline characteristics of diabetic patients and healthy controls } \\
\hline Characteristics & $\begin{array}{l}\text { Control Group } \\
\text { Mean } \pm \text { SE, N=30 }\end{array}$ & $\begin{array}{l}\text { DM Patient Group } \\
\text { Mean } \pm \text { SE, N=61 }\end{array}$ & $\boldsymbol{P}$-value \\
\hline Age (years) & $38.9 \pm 1.5$ & $40.4 \pm 1.3$ & NS* \\
Body Mass Index $(\mathrm{kg} / \mathrm{m} 2)$ & $26.7 \pm 0.74$ & $28.5 \pm 0.72$ & $\mathrm{NS}$ \\
Serum Hs-C Reactive Protein $(\mu \mathrm{g} / \mathrm{ml})$ & $3.3 \pm 0.6$ & $9.2 \pm 1.2$ & $<0.001$ \\
Fasting blood sugar $(\mathrm{mg} / \mathrm{dl})$ & $98.9 \pm 1.4$ & $215.4 \pm 10.7$ & $<0.001$ \\
HbAlc $(\%)$ & $4.9 \pm 0.04$ & $8.5 \pm 0.3$ & $<0.001$ \\
Hemoglobin $(\mathrm{gm} / \mathrm{dl})$ & $14.5 \pm 0.3$ & $13.6 \pm 0.2$ & 0.03 \\
Salivary secretion rate $(\mathrm{ml} / \mathrm{min})$. & $0.34 \pm 0.028$ & $0.29 \pm 0.023$ & $\mathrm{NS}$ \\
Salivary IgA (mg/dl) & $177.3 \pm 11.3$ & $312.4 \pm 15.5$ & $<0.001$ \\
Periodontal index & $0.81 \pm 0.13$ & $1.68 \pm 0.2$ & 0.003 \\
DMFT score & $7.73 \pm 0.61$ & $8.36 \pm 0.58$ & $\mathrm{NS}$ \\
\hline
\end{tabular}

* NS= non-significant 
The relationship between Hs-CRP, salivary IgA, and periodontal parameters with glycemic control in people with diabetes and healthy controls are presented in table 2. As shown, diabetic patients with poor glycemic control had significantly higher periodontal index than that in those with good glycemic control $(P=0.003)$

\begin{tabular}{|c|c|c|c|c|}
\hline \multirow[b]{2}{*}{ Parameters } & \multicolumn{3}{|c|}{ Glycemic Control State } & \multirow{2}{*}{$\begin{array}{l}P \text {-value } \\
\text { ANOVA }\end{array}$} \\
\hline & $\begin{array}{c}\text { Good Control } \\
\mathrm{N}=12\end{array}$ & $\begin{array}{c}\text { Fair Control } \\
\quad \mathbf{N}=10\end{array}$ & $\begin{array}{c}\text { Poor control } \\
\mathbf{N}=39\end{array}$ & \\
\hline $\begin{array}{l}\text { Serum Hs-C Reactive Protein } \\
(\mu \mathrm{g} / \mathrm{ml})\end{array}$ & $7.7 \pm 2.6$ & $8.7 \pm 3.6$ & $9.8 \pm 1.5$ & NS \\
\hline Salivary secretion rate (ml/min) & $0.29 \pm 0.06$ & $0.33 \pm 0.05$ & $0.27 \pm 0.03$ & NS \\
\hline Salivary IgA (mg/dl) & $313.6 \pm 25.9$ & $272.8 \pm 20.6$ & $322.1 \pm 22.3$ & NS \\
\hline Periodontal index & $1.02 \pm 0.21$ & $1.1 \pm 0.28$ & $2.03 \pm 0.28$ & 0.04 \\
\hline $\begin{array}{l}\text { Poor control vs Fair control: } \\
\text { Poor control vs Good control: }\end{array}$ & & & $\begin{array}{l}0.035 \\
0.003\end{array}$ & \\
\hline DMFT score & $8.83 \pm 1.1$ & $10 \pm 1.0$ & $7.8 \pm 0.8$ & NS \\
\hline
\end{tabular}

NS: Non-significant

To determine which of the selected or periodontal parameters was significantly associated with periodontal index level in diabetic patients, we performed ANOVA analysis between the periodontal index and Hs-CRP, salivary secretion rate, salivary
$\operatorname{IgA}$, and DFMT score. The results are presented in table 3. As shown by ANOVA analysis, salivary secretion rate was significantly higher in the group with low periodontal index (0-0.2) compared with those with periodontal index 2 or more $(P=0.032)$.

\begin{tabular}{|c|c|c|c|c|c|}
\hline \multirow[b]{2}{*}{ Parameters } & \multicolumn{4}{|c|}{ Groups of Periodontal Index } & \multirow{2}{*}{$\begin{array}{c}P \text {-value } \\
\text { ANOVA }\end{array}$} \\
\hline & $\begin{array}{c}A(0-0.2) \\
N=9\end{array}$ & $\begin{array}{c}\text { B (0.3-0.9) } \\
\mathrm{N}=12\end{array}$ & $\begin{array}{c}\mathrm{C}(1-1.9) \\
\mathrm{N}=22\end{array}$ & $\begin{array}{l}D(\geq 2) \\
N=18\end{array}$ & \\
\hline Serum Hs-CRP $(\mu \mathrm{g} / \mathrm{ml})$ & $9.8 \pm 1.8$ & $8.7 \pm 2.3$ & $9.2 \pm 2.2$ & $9.4 \pm 2.5$ & NS \\
\hline $\begin{array}{l}\text { Salivary secretion rate } \\
(\mathrm{ml} / \mathrm{min} .)\end{array}$ & $0.39 \pm 0.06$ & $0.28 \pm 0.06$ & $0.29 \pm 0.03$ & $0.22 \pm 0.03$ & 0.032 \\
\hline Group A vs Group D, & & & & $=0.013$ & \\
\hline Salivary IgA (mg/dl) & $286.1 \pm 22.2$ & $318.9 \pm 26.6$ & $320.6 \pm 28.9$ & $311 \pm 34.3$ & NS \\
\hline DMFT score & $7.3 \pm 1.5$ & $9.3 \pm 1.2$ & $7.7 \pm 0.9$ & $9.1 \pm 1.3$ & NS \\
\hline
\end{tabular}

NS: Non-significant

Diabetic patients were divided into three groups according to their DMFT score (A, $\mathrm{B}$, and $\mathrm{C}$ ). All variables were further analyzed in ANOVA analyses; only salivary $\operatorname{IgA}$ level was significantly different between these groups $(\underline{P}=0.039)$ 
as shown in table 4, and it was significantly higher in group $\mathrm{C}$ (DMFT score 13 and more) compared to group A (DMFT score 0-6).

\begin{tabular}{|c|c|c|c|c|}
\hline \multirow[b]{2}{*}{ Parameters } & \multicolumn{3}{|c|}{ Group of DMFT Score } & \multirow{2}{*}{$\begin{array}{c}P \text {-value } \\
\text { ANOVA }\end{array}$} \\
\hline & $\begin{array}{c}A(0-6) \\
N=25\end{array}$ & $\begin{array}{c}\text { B }(7-12) \\
N=25\end{array}$ & $\begin{array}{c}C(\geq 13) \\
N=11\end{array}$ & \\
\hline Serum Hs-C Reactive Protein $(\mu \mathrm{g} / \mathrm{ml})$ & $7.6 \pm 1.7$ & $10.5 \pm 2.1$ & $10.0 \pm 3.2$ & NS \\
\hline Salivary secretion rate (ml/min.) & $0.25 \pm 0.03$ & $0.29 \pm 0.03$ & $0.39 \pm 0.06$ & NS \\
\hline Salivary IgA (mg/dl) & $274.5 \pm 17.8$ & $324.7 \pm 27.1$ & $370.5 \pm 39.7$ & 0.039 \\
\hline Group A vs Group C & \multicolumn{4}{|c|}{$P=0.016$} \\
\hline Periodontal index & $1.76 \pm 0.25$ & $1.5 \pm 0.3$ & $2.15 \pm 0.65$ & NS \\
\hline DMFT score & $4.3 \pm 0.37$ & $9.3 \pm 0.33$ & $15.5 \pm 0.87$ & $<0.001$ \\
\hline
\end{tabular}

NS: Non-significant

\section{DISCUSSION:}

This study showed significantly higher HsCRP and salivary IgA levels in diabetic patients compared with levels in healthy controls. The results confirm a relationship between the periodontal index and glycemic control, as the mean periodontal index in diabetic patients with poor glycemic control was about 2 times higher than that in the good control group, as well as between DMFT and salivary IgA level., as the mean DMFT score was about 3 times in participants with severe dental carries than that with mild dental carries. It has been reported that inflammatory processes are indicated by high Hs-CRP, but data concerning the relation of Hs-CRP levels with the severity of periodontal disease in diabetic patients are scarce. General categories of risk factors associated with the development of periodontitis include genetic, environmental (e.g., tobacco use), and acquired risk factors, e.g., DM and cardiovascular diseases. The elevation in Hs-CRP levels in diabetic patients might be attributed to the enhanced inflammatory process and its complications rather than the severity of the periodontal index. Moreover, CRP is not synthesized locally by the periodontal tissues because CRPmRNA has not been isolated from periodontal tissue ${ }^{15}$. In patients with DM who are susceptible to periodontitis, the above inflammatory process will eventually extend apically and laterally to involve deeper connective tissues and alveolar bone. The possible explanation is that HsCRP and their positive correlation reflect activation of the immune system. In this study, the periodontal index was significantly higher in diabetic patients, with an increase of about two-fold compared with the control group. Many studies have found a higher prevalence of the periodontal disease among diabetic patients than among healthy controls ${ }^{4,11}$. Large epidemiological studies have shown that diabetes increases the risk of alveolar bone loss approximately three-fold compared with non-diabetic individuals. The mechanisms by which diabetes influences the periodontium are similar to the pathophysiology of classic 
microvascular and macrovascular complications. The present study showed a significantly higher periodontal index in people with diabetes with poor glycemic control compared to those with good and fair control; this finding is consistent with previously reported data ${ }^{4,8}$. Moreover, it has been shown that periodontal disease and DM have a two-way relationship; periodontal disease may be a risk factor for the development of type2 DM 4: additionally, diabetic patients with the periodontal infection have worse glycemic control compared with diabetics subjects without periodontal disease ${ }^{15}$. Salivary Secretion Rate (SSR) in both studied groups was not significantly different, and in both groups, SSR were within normal reference values; the average value for SSR of whole saliva in healthy individuals is about $0.3 \mathrm{ml} / \mathrm{min}^{16}$. In this study, subjects spit out the saliva into the test tube once a minute, which may have influenced the flow rate of unstimulated saliva. Panchbhai et al. ${ }^{17}$ and Al-Zahawi et al. ${ }^{18}$ showed that poorly controlled type II DM has no influence on salivary output; however, Harrison and Bowen ${ }^{19}$ concluded that patients with poorly controlled type I DM had the significantly lower flow of the whole saliva compared to well-controlled and healthy subjects. Al-Maroof RH (2010) in line with our finding, he was found that the high concentration of the total proteins level in diabetic patient could be related to the increase in $\operatorname{IgA}$ and amylase levels in IDDM, or may be due to the decrease in the flow rate since, total proteins has an inverse relationship with salivary flow rate. ${ }^{20}$

Results of the present study revealed a highly significant increase in salivary $\operatorname{IgA}$ in diabetic patients. This finding is in agreement with that of Bhuyan et al. ${ }^{21}$. Sardari $\mathrm{F}$ et al. ${ }^{22}$ found that diabetic patients had higher salivary IgA levels compared to non-diabetic individuals. The possible mechanism responsible for increased salivary $\operatorname{Ig} \mathrm{A}$ was sought to the increased severity of periodontal disease in diabetic patients (evidenced by increased periodontal index). In periodontitis, the subgingival plaque accumulation results in an acute inflammatory response with infiltration of lymphocytes and plasma cells and a possible outpouring of immunoglobulins. Data concerning the relation of salivary IgA with DMFT score and dental caries in diabetics, particularly in type II DM, are limited. It has been reported that the bacteria $\mathrm{S}$. mutants is the primary causative agent of dental caries in human beings. The duration of DM has no influence on salivary IgA level, while others found higher salivary IgA in longduration patients with type I DM ${ }^{21,23}$ and they attributed this increase to decreased SSR due to presence of negative correlation between SSR and IgA level; however, in this study SSR was not changed significantly in diabetic patients; also no correlation was found between SSR and salivary IgA levels.

\section{CONCLUSION}

The results confirm that Serum Hs-CRP and salivary $\operatorname{IgA}$ levels are significantly elevated in diabetic patients. These findings may have attributed to the activation of the immune system and inflammation with excess production of pro-inflammatory mediators. As expected, higher levels of the periodontal index are associated with poor glycemic control. Therefore, a primary 
prevention model of reducing blood glucose and inflammation by means of proper oral hygiene and glycemic control may be beneficial in diabetic patients.

\section{REFERENCES}

1. Guyton AC, Hall JE Textbook of medical physiology.13th edition. Elsevier Saunders. Philadelphia, Pennsylvania, USA.2016; 925-29. ISBN: 978-1-4557-7005-2

2. Bhuyan SK, Mody RN, Bhuyan R. Estimation and comparison of serum 9and salivary IgA level in controlled, uncontrolled Diabetics and normal individuals. J Ind. Acad. of Oral Med. and Rad. 2011; 23(4): 548-553.

3. Genco RJ , Williams RC. Periodontal Disease and Overall Health: A Clinician's Guide Overview of Periodontal Disease, $1^{\text {st }}$ Edit. Yardley, USA. 2010; 5-23. ISBN-13: 978-06152-8508-5.

4. Taylor GW, Borgnakke WS, Graves DT. Periodontal disease: associations with diabetes, glycemic control and complications, Oral diseases. 2008; 14(3): 191-203, https://doi.org /10.1111/j.1601-0825.2008.01442.

5. Bakianian VP, Vahedi M, Mortazavi $\mathrm{H}$, Abdollahzadeh Sh, Hajilooi M. Evaluation of salivary glucose, IgA and flow rate in diabetic patients: a case-control study. J Dent. (Tehran) 2010; 7(1): 13-18.

6. Navalkar A, Bhoweer A. Alterations in whole saliva constituents in patients with Diabetes Mellitus and Periodontal Disease. J Indian Academy of Oral
Medicine and Radiology. 2011; 23(4): 498-501.

7. Kakoei S, Hosseini B, Haghdoost AA, Sanjari M, Gholamhosseinian A, Afshar VF. Evaluation of salivary secretory immunoglobulin a levels in diabetic patients and association with Oral and dental manifestations. Sultan Qaboos Univ Med J. 2015; 15(4): 50711.doi:

$$
\text { 10.18295/squmj.2015.15.04.011 }
$$

8. Mehrotra R, Kalontar-Zadeh K, Alder S. Assessment of glycemic control in dialysis patients with diabetes: glycosylated hemoglobin or glycated albumin. Clin J Am Soc Nephrol. 2011; 6 (7): 1520-1522.

9. Jacobson, RH. Factors in selecting serum samples for use in determining the positive/negative threshold (CUTOFF) in ELISA. Chem. 29, 1998 56177.

10. Yadav K, Prakash S. Dental Caries: A Microbiological Approach. J Clin Infect Dis Pract. 2017 (2)118. doi: 10.4172/2476-213X.1000118

11. de Almeida Pdel V, Grégio AM, Machado MA, de Lima AA, Azevedo LR. Saliva composition and functions: A comprehensive review.J Contemp Dent Pract. 2008; 9(3): 72-80.

12. Irfan UM, Dawson DV, Bissada NF. Epidemiology of periodontal disease: a review and clinical perspectives. J Int Acad Periodontol. 2001 Jan; 3(1): 1421.

13. World Health Organization (WHO). Oral health surveys basic methods. 
$19974^{\text {th }}$ edition. World Health Organization. Geneva. Switzerland.

14. Shahrabi M, Nikfarjam J, Alikhani A, Akhoundi N, Ashtiani M, Seraj B. A comparison of salivary calcium, phosphate and alkaline phosphatase in children with severe, moderate caries, and caries free in Tehran's kindergartens. J Indian Soc Pedod Prev Dent. 2008 Jun; 26(2): 74-77. doi: 10.4103/0970-4388.41621.

15. Bhagwat R, Gupte A, Yadav KS. Diagnostic utility of hs-CRP in coronary heart disease. Int J Mol Biol. 2012; 3(1): 36-39.

16. Bültzingslöwen V, Sollecito TP, Fox PC, Daniels T, Jonsson R, Lockhart PB et al. Salivary dysfunction associated with systemic diseases: systematic review and clinical management recommendations. Oral Surg Oral Pathol Oral Radiol Endod. 2007 Mar; 103 Suppl: S57.e1-15. doi: 10.1016/ j.tripleo.

17. Panchbhai AS, Degwekar SS, Bhowte RR. Estimation of salivary glucose, salivary amylase, salivary total protein and salivary flow rate in diabetics in India. J oral sci. 2010; 52 (3): 359-368.

18. Al-Zahawi SM, Al-Barzenji HAM, AlQassab ZA. Effects of diabetes mellitus type II on salivary flow some salivary parameters (total protein, glucose, and amylase) in Erbil City. J Bagh College Dentistry. 2012; 24 (2): 123-127.
19. Harrison R and Bowen WH Flow rate and organic constituents of whole saliva in insulin - dependent diabetic children and adolescents. Pediatric Dentistry. 1987; 9(4): 287-291

20. Al-Maroof RH. Alteration of saliva in insulin dependent diabetic patients and its relation to their periodontal status. Al-Rafidain Dent J. 2010; 10 (1): 102109.

21. BranchoL-de-Almeida LS, Alves CMC, Lopes FF, Pereira AFV, Guerra RNM, Pereira ALA Salivary IgA and periodontal treatment need in diabetic patients. Braz Oral Res. 2011; 25 (6), 550-555.

22. Sardari F, Tahmasbi A, Ghanbarzadegan A. Salivary IgA concentration in diabetic patients compared to healthy controls. Dental hypotheses. 2015; (6)2, 60-64 DOI: $10.4103 / 2155-8213.158478$

23. Al-Rawi N, El-Samarrai S. Salivary and serum immune system in relation to carries-experience among type 1 insulin-dependent diabetic children. J Bagh College Dentistry. 2010; 22 (2): 108-112. 


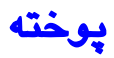

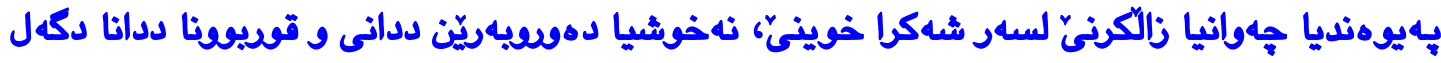

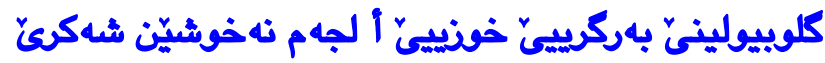

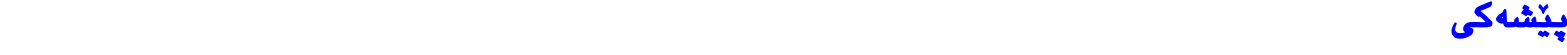

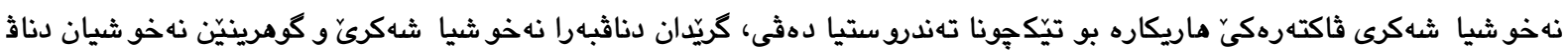

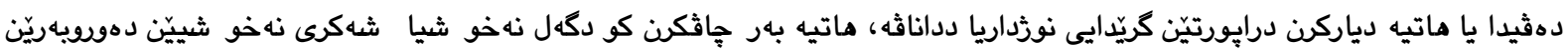

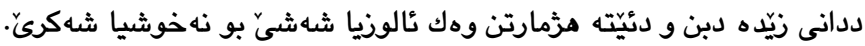

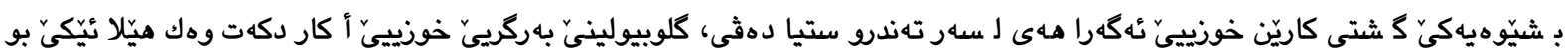

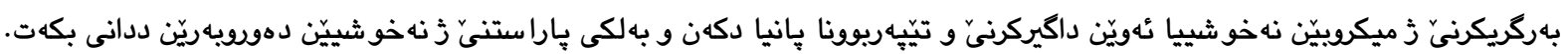

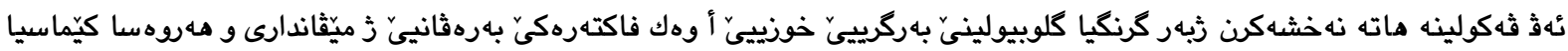

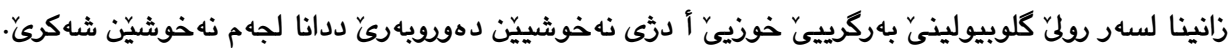

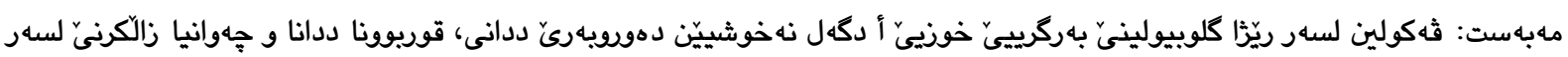
شهكرا خوينى لجه م نه خوشيّن شهكريّ.

كهس وريَكيّن ثهكولينيّ

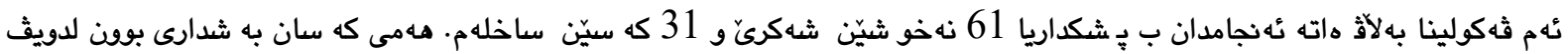

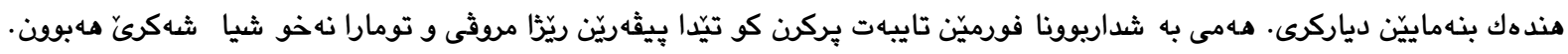

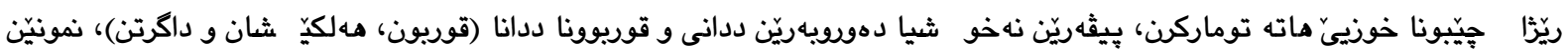

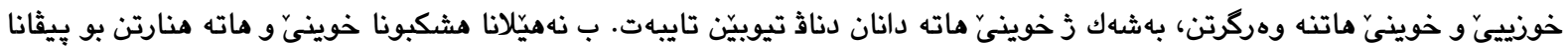

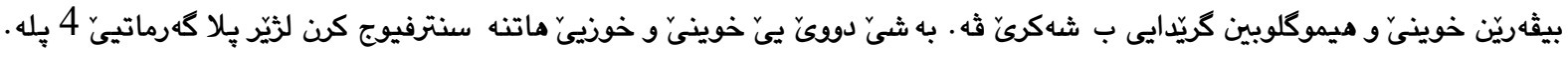

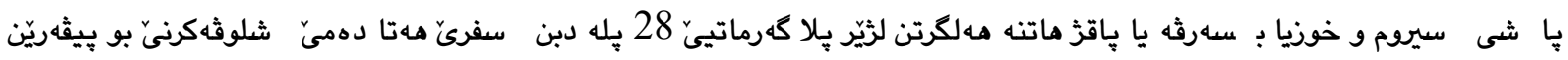

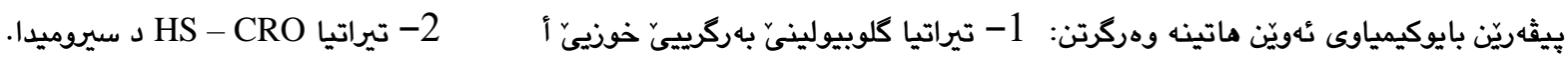

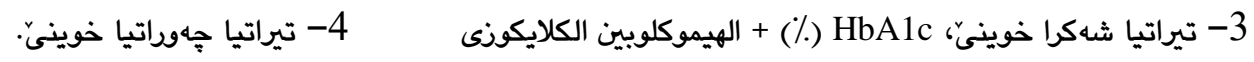

تهنجام

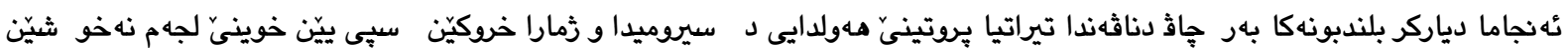

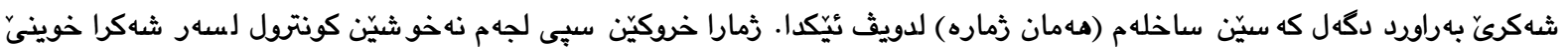

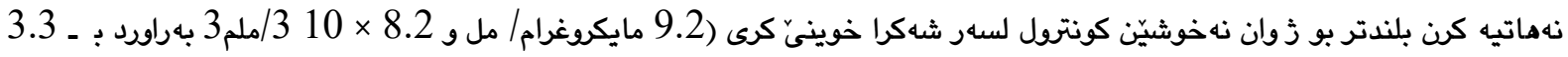

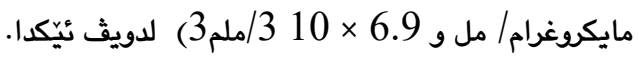

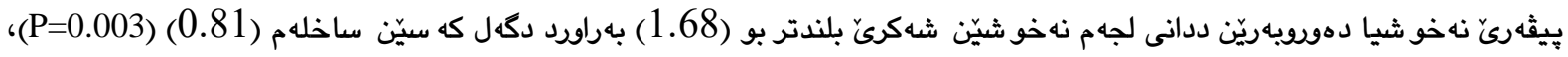

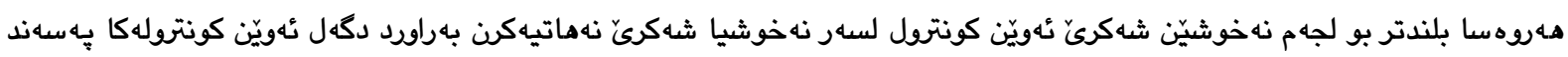

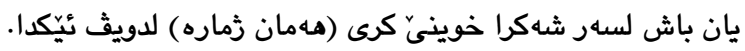

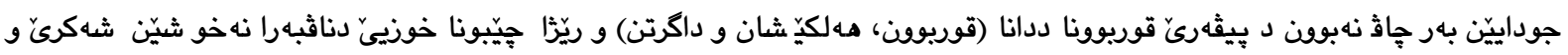

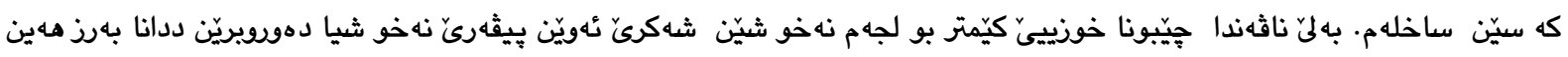

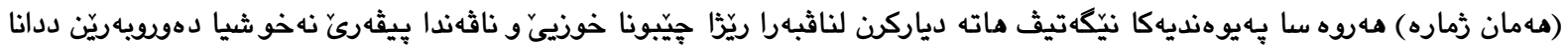

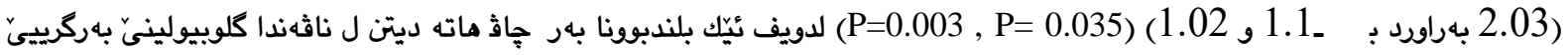

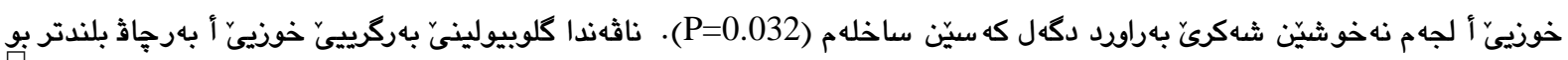

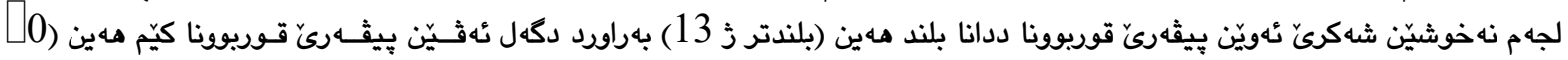




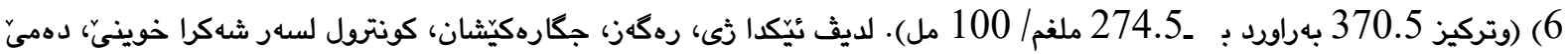

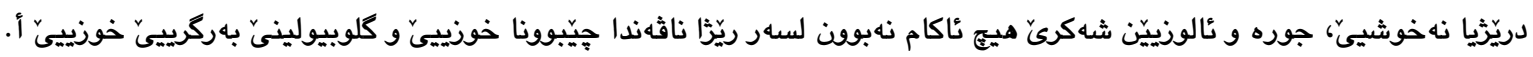

دهرئهنجام

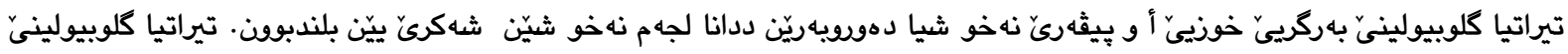

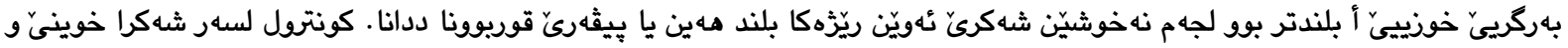

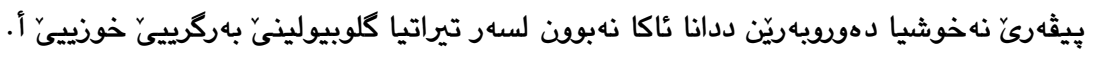
الخلاصة

\section{مستويات البروتين التفاعلي (ج) في مصل الام والكلوبيولين المناعي اللعابي أ ممكن أن يعكسان شدة

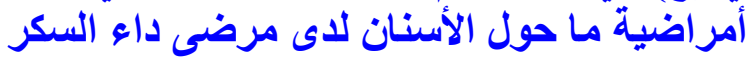

خلفية البحث

يعتبرداءالسكري كعامل خطر مضر بصحة الفم, كانت العلاقة بين مرض السكري و التغيرات المرضية في تجويف الفم

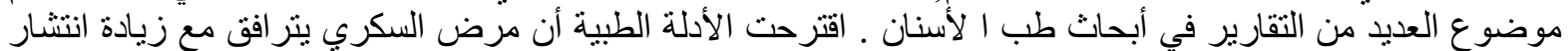

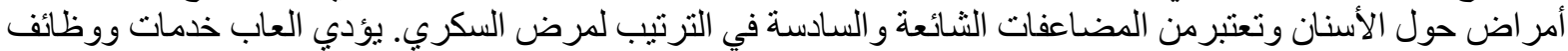

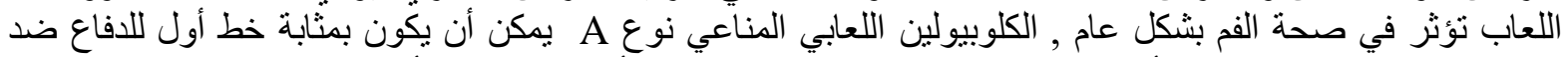

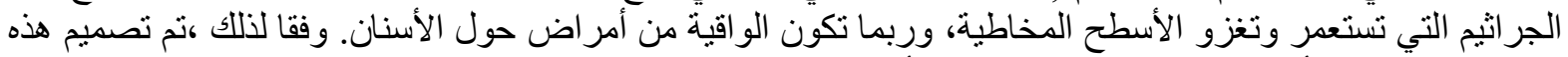

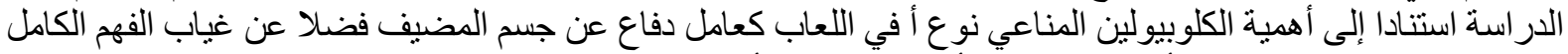

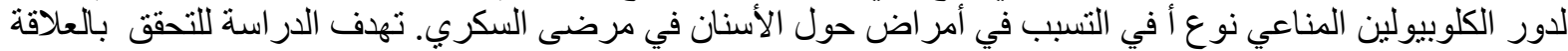

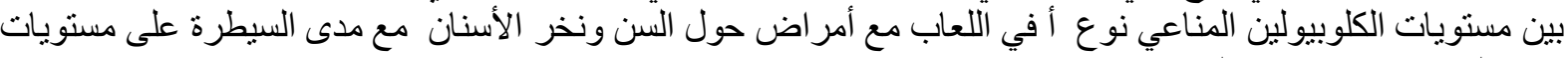
سكر الدم في مرضى داء السكري.

\section{الاشخاص وطرق البحث}

شارك في هذه الدر اسة المقطعية 61 مريضاً يعانون من داء السكري و30 من الأصحاء ظاهريا والمتجانسين مع عينة البحث

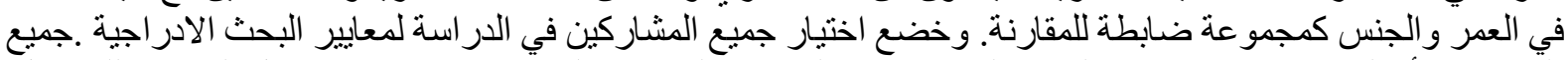

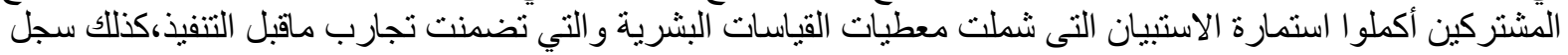

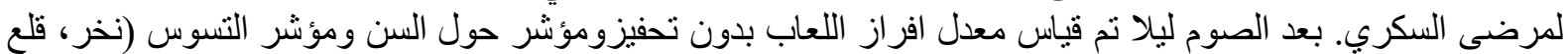

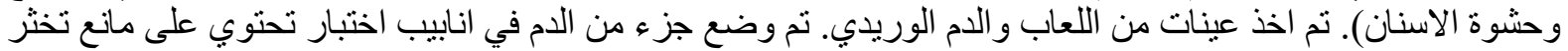

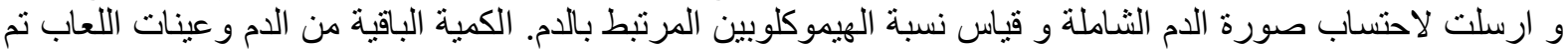

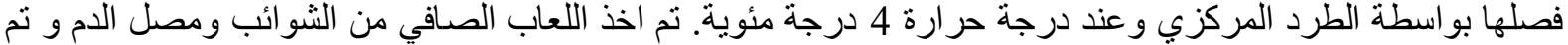

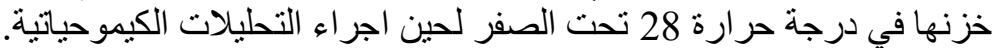
تم اجر اء التحليلات الكيموحياتية التالية:

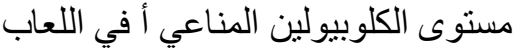

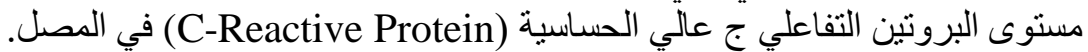

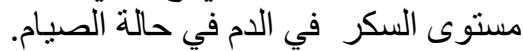

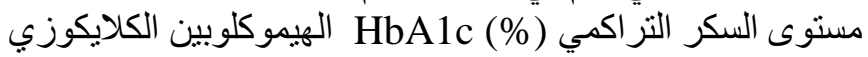

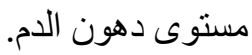

النتائج والمناقشة اظهرت النتائج زيادة معنوية في معدل مستوى البروتين التفاعلي ج في المصل لدى مرضى السكري مقارنة بالاشخاص

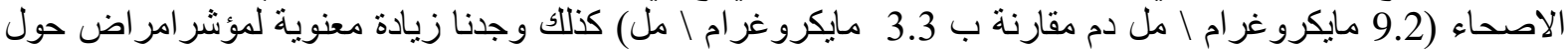

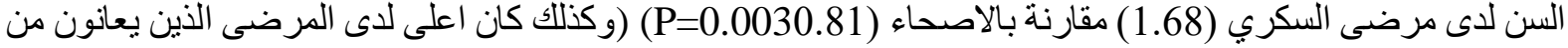

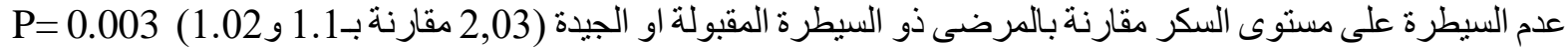
( P=0.035) لم يلاحظو جود فروقات احصائية في مؤشر التسوس (نخر ، قلع وحشوة الاسنان) ومتوسط إفراز اللعاب بين مرضى السكري

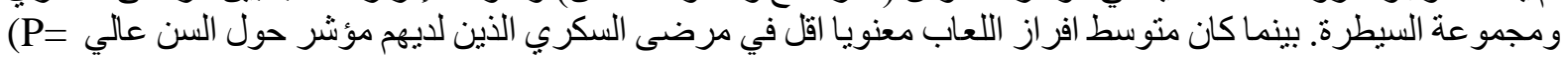

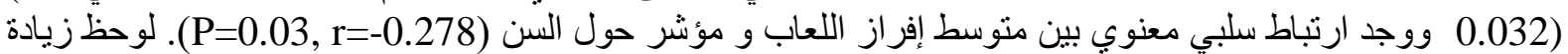

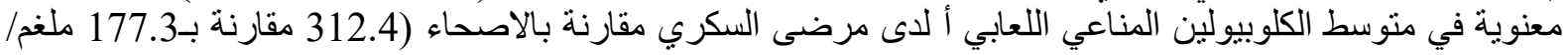




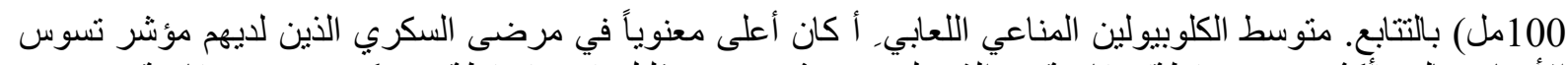

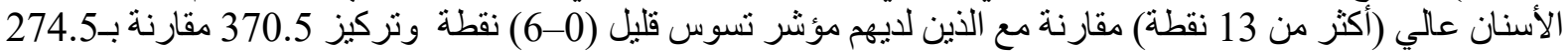

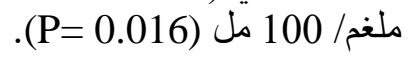

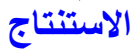

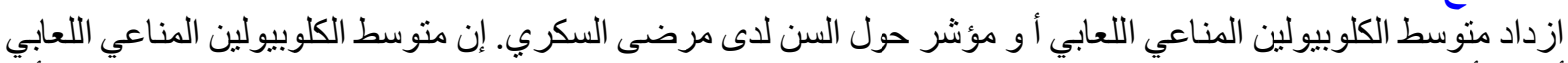

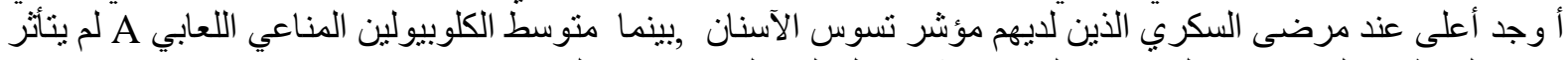

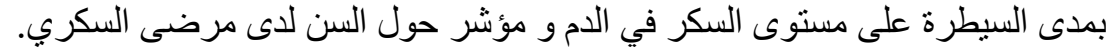

